\title{
The effect of conservatism on accrual and stock return
}

\author{
Hajar Sanechi Motlagh ${ }^{1, *}$, Somaye Sanechi MotLaGH ${ }^{2}$ \\ ${ }^{1}$ Department of Accounting, Shahid Chamran University of Ahvaz, Ahvaz, Iran \\ ${ }^{2}$ Department of Financial Management, Islamic Azad University, Electronic Branch, Tehran, \\ Iran
}

*Corresponding Author: inamds66@gmail.com

\begin{abstract}
According to representation theory, hope of future good news stimulates the managers to postepone bad economic news in order to gain extra return. But in fact conservatism in accounting, as an influential control mechanism in identifying the good versus bad economic news, prevent the managers from over-optimism and provides a framework for identifying economic affairs. Therefore, it is the intention of this research to study the aforementioned challenge through analyzing the relation between conservatism, accrual persistence asymmetry and stock return. Conservatism is considered as independent variable of the research and accrual persistence asymmetry and stock return as dependent variables. Moreover, Basu's model its used for measuring conservatism and to control risk, stock return is moderated in extent. Admitted firms in Tehran's Bond Exchange from 2009 to 2015 constitude the date of the present research from which a sum of 66 firms (462 year-firm) are placed within the sample data of this research. The assumption of the research are tested via analyzing coefficient variables?regression modeling findings of the research suggest that there exists no meaningful relation between resistance of accrual items and stock return and another analysis rejected the existence of such relation has been rejected which suggested that law makings and standards are weak in a way that provide the ground for manipulating the real activities altimately leading to increased operational risks.
\end{abstract}

Keywords: conservatism, accruals, stock returns, financial reporting, financial statements

\section{Introduction}

On the basis of accepted accounting principles, companies are using accrual accounting that according to "financial effects of transactions and other events and events that generates cash flow for the company in record times and those transactions and events have been fulfilled. The 
nature of accrual accounting gives managers great discretion to determine earnings per reporting period by the accruals.

In general, managers have considerable control over the timing of expense items (such as research and expenditures of research and development). And to some extent can modify the time of revenue recognition (such as sales on credit) or follow delaying in identification through creating storage. Being conservatives by limiting earnings management and improving the level of information disclosure could lead to improve the information environment (Dikravat 2012) and by rapid detection of bad economic news than good economic news lead to increasing in the level of disclosure of accounting information quality, changing the transaction behavior of unaware or ignorant investors and reducing uncertainty about the value of the company (Brown and Hayjlst 2011. And this important issue, in turn, reduces information asymmetry and incorrect selection problem, increases market efficiency, and stock market value will be closer to the intrinsic value of stock and the market will reduce abnormal returns. So in this study, conservatism is used to enhance the stability of accruals and stock returns.

\section{Theoretical framework}

As companies are under growing pressure in economic disadvantage, managers ask accountancy unit to improve the last line of financial statements (profit) and thereby to change its information content. Data for this decision is very complex issue because its diverse range of users, such as investors, managers, banks and funders requires different information. (Noravesh et al., 1384). Financial statements constitute the main part of the financial reporting processes (Technical Committee of Audit organization, 1381, p.481). The purpose of financial statements is providing summarized and classified information about the financial position, financial performance and financial Flexibility of trade unit. That is useful for the wide range of users of financial statements in making economic decisions. The purpose of financial reporting and accounting principles requires providing financial reporting information that has certain features (Research Center for Accounting and Auditing, 1385, p. 49). In the theoretical framework of financial reporting of Iran, these features are mentioned as qualitative characteristics. One of these features is conservatism which has been referred as a precaution. While most of the accountant accept conservatism, but so far no general definition of conservatism is offered.

Two types of conservatism are defined in the accounting literature. First, the existence of bias in offering less than the book value to its market value that is offered by FeltSam \& Olson in 1995 in which represents the conservatism from the standpoint of the balance sheet and the criterion of the ratio of market value to book value is derived from this definition. And second one is the desire to speed up identifying losses and postponing the recognition of profits which represents the conservative from the standpoint of profit and loss viewpoint. And accordingly, Basu in 1997 introduced the time asymmetry measure. Today, with the development of trading mechanisms in stock market, information is considered an important tool in economic decision-making. And certainly, the quality of decisions on the validity, accuracy and timeliness of information depends 
on whether they provided by issuers of stocks and active brokers in this market and are available to interested parties such as shareholders. However, with an emphasis on rational choice theory, there is always the possibility that that publishers information who have more information from the company's financial situation provide the information for outsiders with bias. And by gaining more efficiency than other groups maximize their own interests. The contrast of such views with the labor market hypothesis causes the issue of abnormal returns in recent decades is considered by many researchers. The results of these studies indicate that the use of procedures such as conservatism as appropriate control mechanisms in the field of publication of financial statements that are prepared in accordance with accounting standards and considered as one of the important linkages between insiders and outsiders of organization can reduce the abnormal returns and lead capital markets to efficient markets. Financial Accounting Standards Board has stated in its conceptual statement No.1 that financial reporting should help investors, creditors and other parties in assessing the amount, timing and uncertainty of future cash flows. In addition, the Board, however; tacitly accepted cash flow valuation model but believes that the accrual accounting system of information for predicting future cash flows is more useful than information based on cash receipts and payments:

Accrual accounting is usually providing a better indicator of current and ongoing ability of trade unit to generate future cash flows than information limited to the effects of receipts and payments. The nature of accrual accounting gives managers a great discretion to determine earnings per reporting period by the accruals. In general, managers have considerable control over the timing of expense items (such as research and expenditures of research and development). And to some extent can modify the time of revenue recognition (such as sales on credit) or follow delaying in identification through creating storage (Mehrani et al., 1390).

Research indicates the stability of the accruals less than the cash flow (Slown, 1996). This instability of accruals leads to increase uncertainty about the reported information. And, therefore, risk is increased and at the result, dramatic pricing of accruals (accrual anomaly) is reasonable.

Other justification for the accrual anomaly is based on the fact that changes in accruals related to the change in investment. Thus, an increase in accruals means an increase in investment that by increasing this investment a gradual decline in the return on investment should be seen. So it would be reasonable to see low prices for stocks of companies with high accruals and high prices for companies with low accruals that it means the accrual anomaly.

If the estimation of low reliable accruals provides an error measurement, profits 'stability would be reduced and if investors do not predict lower stability of low reliable accruals, this may lead to wrong pricing. This may lead to market failure and inefficient allotment of scarce resources and efficient capital distribution and accumulation processes will be problematic. And scale savings, economic development and social welfare will be at risk. 
Accounting conservatism is closely connected with in principle with commitment items, because commitment items are prone to manipulation and always need evaluation and the goal of conservatism is limiting the manipulation and mistakes in estimations which increase income ( Watts,2003, Lafond and Watts 2008). In fact a principle of accounting (conservatism) can decrease mistakes in pricing by another accounting principle (commitment basis).

Most researchers believe that if necessary information is not equally distributed among people, various results regarding a single issue can come to beings and as a result, people who have access to confidential information will benefit more. Therefore, the ones can have consistent additional benefits who have consistent access to confidential information or compared to other investors have special capacity to achieve unusual consistent benefits based on public information. ( Raee, Talangi -1387). Some examples of such people who have access to such information are administrators or people who are within the organization. Based on the representation theory which is derived of the games theory, it is possible that administrators as representatives of investors act or make some decisions which do not necessarily maximize shareholders' wealth.

Watts (2003) recommends that conservatism result in more ability of reliability of commitment items which are related to benefits. Richardson et al. (2005), empirically state that the ability of reliability of most of commitment items result in more consistency of anticipation of future benefits. Therefore corporations with high commitment basis and conservatism have more consistent benefits compared with the ones with high commitment basis and low conservatism.

\section{Background of research}

\subsection{Foreign Studies}

Garcia et al. (2012, using U.S. corporate data, observed the effects of conservatism on management of benefits which is based on commitment items and the real management of benefits. Their results showed that more conservatism results in decreasing the management of benefits based on commitment items and increasing the real management of benefits.

Ahmed and Duellman (2007) studied the relationship between conservatism and corporate navigation mechanism. They used company size, debts and improvement chances as control variables.Using three conservatism measures called lack of time symmetry, commitment items and market values, they showed that there are such relationships between these factors: (a) commitment item measure, positive and meaningful relationship, (b) market value measure, no meaningful relationship, (c) lack of time symmetry, no meaningful relationship.

Lev and Nissim (2004), observing the consistency of commitment items, showed that the negative relationship between commitment items and the future efficiency of shares, supposing that market has no efficiency, results in people using Arbitrage opportunities and achieve benefits after finding out about these relationships. They showed that these disagreements 
existed and did not decrease during the past decade. However, because the large number of transactions and the expense of information related to using the commitment items, the speed of reaction of people is not very high.

Basu (1997) in his study entitled measuring the conservatism, supposed that the efficiency of shares of each year includes the good and bad news about the financial process which is expected in the future. Also they supposed that conservatism results in bad news being recognized more in time than the good one regarding benefits and loss. This shows that the slope of regression between benefits and efficiency, is higher for the corporations having bad news ( negative efficiency) than the ones having good news ( positive efficiency)

\subsection{Stidies in Iran}

Karami and Omrani (1389) studied the relationship between the effect life cycle of companies and conservatism on the company value. The results show that during the stages of growth, investors pay more attention to the net price of operative properties and the unusual operative benefits of conservative companies (than companies using bold accounting processes). During the decline stage the condition is reversed.

Ghaemi et al. (1389) studied the effect of conservative accounting on the consistency of benefits and the ratio of price to benefits. The results show that the consistency of benefit is lower in companies which report the more conservative benefits. Also, the ratio of price to benefits of companies which report conservative benefits is also lower.

Mehrani et al. (1388) studied the relationship between conservatism and the commitment items of benefits. the results indicated that in Iran captive market, the benefit of accounting of companies is more sensitive to the negative efficiency ( compared to the positive efficiency). and the commitment items explain most of the lack of time symmetry in benefits.

Banimahd (1385) in a study called "the expression and presentation of patterns for measuring the conservatism, in accounting", firstly identified the effective parameters on accounting and secondly presented a measurable pattern for conservatism in accounting. The results showed that accounting conservatism decreased in the companies under the study. This is because of decreasing in the commitment and financial efficiency in the companies under the study.

\subsection{The Research Hypotheses}

Regarding the results of the previous studies and based on the presented views about the accounting conservatism limiting most successful manipulation chances on commitment items, it is expected that there is positive relationship between conservatism and accrual persistence. Therefore the first hypothesis is stated as follows: 


\section{Higher degree of conservatism increase the persistence of accruals in high accrual firms.}

Also it is stated that conservatism as a qualitative feature of financial information, on one hand improves the quality of financial information and decreases the information risk of companies and on the other hand, decreasing the lack of information symmetry among engaged beneficiaries, results in decreasing pricing lower than the real price and finally increasing the efficiency. Therefore, regarding theses issues the second hypothesis of the research is stated as follows:

Higher degree of conservatism increase future returns related to accruals in high accrual firms.

\subsection{The Methodology}

The statistical population of this study, are the companies which are accepted in the securities exchange of Tehran which were in the list of stock exchange companies since 1386 until 1392. Samples of this study includes companies having these features:

1) The companies must have consistent activity during a financial year;

2) Companies must not be of intermediation industry, investing, leasing types or of insurance companies

3) In order to have the ability to compare information, the financial period of companies must finish at the end of Esfand.

4) The financial statements of companies must be audited.

5) Companies must have complete information for all financial statements like balance sheets, income statement and cash flow statements.

This study, regarding the purpose view is an applied one and regarding the nature is semiempirical. For gathering data regarding hypotheses and variables the database of stock exchange and security exchange organization of Tehran, the Rahavard Novin financial software and the fund statements of companies were used. The fund statements of companies were directly used. The final analysis was done by EVIEWS and EXCEL softwares.

\section{Models and variables of the study}

The variables categorized as independent and dependent are as follows:

The dependant variables in this research are commitment items and share efficiency. 
The commitment items:

In order to account the commitment items the following formula is used.

Total of accruals:

Equation below provides the calculation of accruals:

$$
\mathrm{TACC}_{i, \mathrm{t}}=\mathrm{CACC}_{\mathrm{i}, \mathrm{t}}+\mathrm{NCACC}_{\mathrm{i}, \mathrm{t}}
$$

Where TACC is total accruals, CACC is the accrual of working capital that is derived of the following formula:

$$
\mathrm{CACC}_{\mathrm{i}, \mathrm{t}}=\Delta\left(\mathrm{CA}_{\mathrm{i}, \mathrm{t}}-\mathrm{C}_{\mathrm{i}, \mathrm{t}}\right)-\Delta\left(\mathrm{CL}_{\mathrm{i}, \mathrm{t}}-\mathrm{STD}_{\mathrm{i}, \mathrm{t}}\right)
$$

Where $\triangle \mathrm{CA}$ is change in current asset, $\Delta \mathrm{C}$ is change in cash and cash equivalents, $\Delta \mathrm{CL}$ is change in current liabilities, $\triangle$ STD is change in current debt.

NCACC is long term accruals which is the result of the following formula:

$\Delta\left(\mathrm{TA}_{\mathrm{i}, \mathrm{t}}-\mathrm{CA}_{\mathrm{i}, \mathrm{t}}\right)-\Delta\left(\mathrm{TL}_{\mathrm{i}, \mathrm{t}}-\mathrm{CL}_{\mathrm{i}, \mathrm{t}}-\mathrm{LTD}_{\mathrm{i}, \mathrm{t}}\right) \mathrm{NCACC}_{\mathrm{i}, \mathrm{t}}=$

Where $\triangle \mathrm{TA}$ is change in total asset, $\triangle \mathrm{CA}$ is change in cuurent asset, $\Delta \mathrm{TL}$ is change in total liability, $\triangle \mathrm{CL}$ is change in current liability, $\triangle \mathrm{LTD}$ is change in long term liability.

Another dependent variable in this study, like Papanastasopoulos et al. (2011) is the adjusted return based on the size. Regarding that companies' deadline for publish financial statements is four months after the end of a financial year, the period of calculation of return of each year is determined from the fifth month after the financial year and its length is 12 months. Also in order to control the risk, the return of the stock must be adjusted regarding its size. For this purpose, firstly the companies are organized from small to big based on the market value on aApril $21^{\text {st }}$. After this stage, the sample companies must be divided into four quarters. After determining the quarters and calculating the monthly return of companies, the geometric mean of stock return and the adjusted one of the stock return of each company in each quarter is calculated. ( Using the 12-month return mean instead of yearly return is for more accuracy. ) At the end, for controlling the effect of size on the monthly return of the capital of each company, the adjusted return is calculated based on the size using the following formula: 


$$
\mathrm{r}_{\mathrm{E}, \mathrm{t}}^{\mathrm{giz}-\mathrm{adj}}=\mathrm{r}_{\mathrm{E}, \mathrm{t}}-\mathrm{r}_{\mathrm{g}, \mathrm{t}} \Rightarrow \mathrm{SAR}=\prod_{\mathrm{t}=1}^{\mathrm{m}}\left(1+\mathrm{r}_{\mathrm{it}}\right)-\prod_{\mathrm{t}=1}^{\mathrm{m}}\left(1+\mathrm{R}_{\mathrm{g}, \mathrm{t}}\right)
$$

In this formula:

Where SAR the adjusted return based on size,

$\mathbf{R}_{s, t}$ the monthly balanced portfolio return,

$r_{\mathrm{it}}$ the monthly return of company capital.

The independent variable is conservatism that is calculated by Basu model (1997).

$\mathrm{Xit} /$ Pit-1 $=\alpha+\beta 1 \mathrm{DR}$ it $+\beta 2$ Rit $+\beta 3$ (Rit $\mathrm{x}$ DRit $)+\varepsilon$ it

Where $\mathrm{X}$ is earnings per share before extra-ordinary items and discontinued operations, $\mathrm{R}$ is the annual cum dividend return, DR is a dummy variable, which equals 1 , when returns are negative, and 0 otherwise; and $\mathrm{P}$ is the end of prior fiscal year stock price. The main coefficient of interest is $\beta 3$, which represents the incremental effect on contemporaneous earnings from negative returns (coined 'bad news' in Basu's article), in comparison to positive returns (good news). A positive and statistically significant $\beta 3$ is interpreted as showing the existence of accounting conservatism. Following Francis, Lafond, Olsson, and Schipper (2004) and Zhang (2008), we use the sensitivity of earnings to negative returns $(\beta 2+\beta 3)$, relative to positive returns $(\beta 2)$, as a proxy for this firm-level degree of conservatism. Formally, we call this the asymmetric timeliness measure of conservatism: $\mathrm{AT}=(\beta 2+\beta 3 / \beta 2)$. This quotient is calculated on a rolling ten-year window, $\mathrm{t}-9, \ldots, \mathrm{t}$, requiring a minimum of five years, and an unbiased estimate of $\beta 3$ for a firm to be given an AT measure of conservatism.

To measure earnings persistence of cash flows, accruals, conservatism, and the combined effect of conservatism and accruals we use the following equation:

$=\alpha+\beta 1 \mathrm{CFO}_{\mathrm{ir}}+\beta 2 \mathrm{OAC}_{\mathrm{ir}}+\beta 3 \mathrm{CONSQ}_{\mathrm{ir}}+\beta 4\left(\mathrm{CONSQ}_{\mathrm{ir}} * \mathrm{OAC}_{\mathrm{ir}}\right)+\varepsilon_{\mathrm{i}, \mathrm{t}+1} \mathrm{INC}_{\mathrm{i}, \mathrm{t}+1}$

Where OAC is operating accruals, CFO is cash flow from operations, INC is income before extra-ordinary items, and CONSQ is the composite proxy for conservatism. The interaction variable CONSQ*OAC will beused to demonstrate whether conservatism affects accrual persistence. The subscripts $\mathrm{i}$ and $\mathrm{t}$ represent firm and fiscal year, respectively, and all continuous variables are deflated by AVGA to control for scale differences.

Next, for the firm-level relationship between future size-adjusted returns and firm-level accruals, conservatism, and their interaction we use the followed model: 


$$
\begin{aligned}
\text { SAR }_{\mathrm{jt}+1}=\beta_{0} & +\beta_{1} \text { DIVY }_{\mathrm{jt}}+\beta_{2} \text { DIVY2 }_{\mathrm{jt}}+\beta_{3} \text { BETA }_{\mathrm{jt}}+\beta_{4} \operatorname{LnBTM}_{\mathrm{jt}}+\beta_{5} \operatorname{LnMV}_{\mathrm{jt}}+\beta_{6} \text { LEV }_{\mathrm{jt}} \\
& +\beta_{7} \text { EYLD }_{\mathrm{jt}}+\beta_{\mathrm{g}} \text { NEYLD }_{\mathrm{jt}}+\beta_{9} \text { CFO }_{\mathrm{jt}}+\beta_{10} \text { OAC }_{\mathrm{jt}}+\beta_{11} \operatorname{CONSQ}_{\mathrm{jt}}+\beta_{12} \operatorname{CONSQ}_{\mathrm{jt}} \\
& +\mathrm{OAC}_{\mathrm{jt}}+\mathrm{\varepsilon}_{\mathrm{jt}}
\end{aligned}
$$

Where SAR is future stock return, DIVY = dividend yield in percent and DIVY2 is the dividend yield squared, BETA is capital asset pricing model beta, LnMV and LnBTM are the natural logarithms of market value of common stock and book value to market value of equity respectively, LEV is leverage, calculated as book value of total assets to book value of equity, EYLD is earnings-to-price ratio NEYLD is a negative earnings indicator that equals 1 if earnings are negative, and 0 otherwise.

\section{Findings}

\subsection{Descriptive statistics}

For presenting a general view of important features of calculated variables, in table (1) some of the concepts of descriptive statistics of these variables are presented, including the number of

\begin{tabular}{|c|c|c|c|c|c|c|c|}
\hline \multirow{2}{*}{ Variables } & \multicolumn{2}{|c|}{$\begin{array}{c}\text { Measure of central } \\
\text { tendency }\end{array}$} & \multicolumn{3}{|c|}{ Indexces of dispersion } & \multicolumn{2}{|c|}{$\begin{array}{c}\text { Indexes of } \\
\text { distribution }\end{array}$} \\
\hline & number & mean & $\begin{array}{c}\text { Standard } \\
\text { diviation }\end{array}$ & $\min$ & $\max$ & $\begin{array}{l}\text { kurtos } \\
\text { is }\end{array}$ & skewness \\
\hline $\begin{array}{c}\text { Cash flow from } \\
\text { operation }\end{array}$ & 462 & 612,496 & $2,117,128$ & $-2,499,452$ & $38,653,019$ & 5,72 & 37,5 \\
\hline $\begin{array}{c}\text { Book value of } \\
\text { equity }\end{array}$ & 462 & $1,727,388$ & $5,947,632$ & $-2,059,366$ & $71,664,830$ & 7,23 & 63,7 \\
\hline $\begin{array}{c}\text { Market value of } \\
\text { equity }\end{array}$ & 462 & $3,840,795$ & $13,305,255$ & 18,250 & $155,628,000$ & 6,89 & 57,5 \\
\hline $\begin{array}{c}\text { Book to market } \\
\text { value }\end{array}$ & 462 & 0,679 & 0,818 & $-1,03$ & 14,67 & 11,19 & 185,9 \\
\hline Profit & 462 & 716,340 & $2,585,492$ & $-2,411,961$ & $30,887,476$ & 6,7 & 56,3 \\
\hline Operation accrual & 462 & 474,567 & $3,991,652$ & $-31,774,640$ & $52,080,378$ & 5,35 & 80,6 \\
\hline Leverage & 462 & 6,58 & 5,48 & 0,00 & 35,7 & 2,03 & 6,12 \\
\hline $\begin{array}{l}\text { Earning to price } \\
\text { ratio }\end{array}$ & 462 & 0,167 & 0,171 & $-1,79$ & 0,6 & $-5,27$ & 49,03 \\
\hline Dividend yeild & 462 & 0,8040 & 2,92 & $-50,97$ & 20,03 & $-10,66$ & 219,1 \\
\hline Conservatism & 462 & 0,223 & 153,8 & $-1330,5$ & 2395 & 5,74 & 148,1 \\
\hline DPS & 462 & 867 & 983 & 0 & 7500 & 2,55 & 8,99 \\
\hline BETA & 462 & 0,813 & 2,88 & $-5,01$ & 43 & 11,5 & 151,4 \\
\hline $\begin{array}{c}\text { Future stock } \\
\text { return }\end{array}$ & 462 & 1,41 & 3,8 & $-16,25$ & 22,24 & 0,843 & 6,64 \\
\hline
\end{tabular}
observations, mean, standard deviation, minimum and maximum of observations

Table 1: The descriptive statistics of variables 
Regarding the above table, the findings show that the mean of cash flow of operations under the study was 612,496 million which was from 38,653,019 million until -2,499,452 million rials. The book value of equity also shows that the companies under the study had the average value $1,727,388$ million during the study period whose fewest value was $-2,059,366$. The reason of the negative number of book value was the accumulated loss of more than 100 of other items of equity. These companies were included under the law article 141 and solved this problem in the future.

\subsection{Correlation between independent variables}

For determining the type of distribution of independent variables, the Kolmogorov-Smirnov test was done and regarding the normality of distribution of independent variables, the Pearson test was used to observe the correlation between variables. The correlation matrix between variables is presented in table (2). Regarding the results in the table, it can be concluded that the possibility of fitness of the study model is possible with all explanatory variables present at the same time. Moreover, the multicollinearity of the explanatory variables is tested via the multicollinearity test whose results show that there is no multicollinearity problem between variables. 
Bulletin de la Société Royale des Sciences de Liège, Vol. 86, special edition, 2017, p. 587 - 601

\begin{tabular}{|c|c|c|c|c|c|c|c|c|c|c|c|c|c|c|}
\hline Variables & 1 & 2 & 3 & 4 & 5 & 6 & 7 & 8 & 9 & 10 & 11 & 12 & 13 & 14 \\
\hline \multirow[t]{2}{*}{ INC } & 1 & & & & & & & & & & & & & \\
\hline & - & & & & & & & & & & & & & \\
\hline \multirow[t]{2}{*}{$\mathrm{CFO}$} & 0.40 & 1 & & & & & & & & & & & & \\
\hline & 0.00 & - & & & & & & & & & & & & \\
\hline \multirow[t]{2}{*}{ CONSQ } & -0.02 & 0.00 & 1 & & & & & & & & & & & \\
\hline & 0.587 & 1.00 & - & & & & & & & & & & & \\
\hline \multirow[t]{2}{*}{ CONSQ*OAC } & 0.03 & -.0 .05 & -0.73 & 1 & & & & & & & & & & \\
\hline & 0.496 & 0.223 & 0.00 & - & & & & & & & & & & \\
\hline \multirow[t]{2}{*}{ SAR } & 0.17 & 0.06 & 0.01 & -0.06 & 1 & & & & & & & & & \\
\hline & 0.00 & 0.184 & 0.782 & 0.160 & - & & & & & & & & & \\
\hline \multirow[t]{2}{*}{$\mathrm{OAC}$} & 0.14 & -0.04 & -0.07 & 0.13 & 0.03 & 1 & & & & & & & & \\
\hline & 0.002 & 0.388 & 0.123 & 0.004 & 0.457 & - & & & & & & & & \\
\hline \multirow[t]{2}{*}{ DIVY } & -0.02 & -0.03 & 0.00 & 0.00 & 0.12 & 0.03 & 1 & & & & & & & \\
\hline & 0.655 & 0.457 & 0.912 & 0.901 & 0.009 & 0.498 & - & & & & & & & \\
\hline \multirow[t]{2}{*}{ DIVY^2 } & 0.00 & 0.01 & 0.00 & 0.00 & -0.14 & -0.03 & -0.70 & 1 & & & & & & \\
\hline & 0.998 & 0.761 & 0.985 & 0.958 & 0.001 & 0.406 & 0.00 & - & & & & & & \\
\hline \multirow[t]{2}{*}{ EYLD } & 0.20 & 0.04 & 0.00 & 0.01 & 0.07 & 0.05 & 0.06 & -0.06 & 1 & & & & & \\
\hline & 0.00 & 0.363 & 0.866 & 0.750 & 0.125 & 0.245 & 0.185 & 0.201 & - & & & & & \\
\hline \multirow{2}{*}{ NEYLD } & 0.26 & 0.04 & 0.00 & 0.00 & 0.23 & 0.00 & 0.25 & -0.20 & 0.65 & 1 & & & & \\
\hline & 0.00 & 0.331 & 0.958 & 0.916 & 0.00 & 0.958 & 0.00 & 0.00 & 0.00 & - & & & & \\
\hline \multirow[t]{2}{*}{ LEV } & -0.08 & -0.08 & -0.04 & 0.04 & 0.02 & 0.31 & -0.05 & 0.00 & -0.05 & -0.03 & 1 & & & \\
\hline & 0.076 & 0.056 & 0.371 & 0.302 & 0.593 & 0.00 & 0.207 & 0.944 & 0.230 & 0.446 & - & & & \\
\hline \multirow[t]{2}{*}{ LnBTM } & -0.51 & -0.31 & -0.04 & 0.07 & -0.28 & 0.00 & 0.05 & 0.04 & 0.06 & -0.13 & -0.01 & 1 & & \\
\hline & 0.00 & 0.00 & 0.319 & 0.114 & 0.00 & 0.949 & 0.212 & 0.395 & 0.144 & 0.003 & 0.772 & - & & \\
\hline \multirow[t]{2}{*}{ LnMV } & 0.40 & 0.22 & 0.01 & -0.03 & 0.14 & 0.09 & 0.00 & -0.02 & 0.01 & 0.11 & -0.01 & -0.40 & 1 & \\
\hline & 0.00 & 0.00 & 0.707 & 0.514 & 0.002 & 0.045 & 0.866 & 0.557 & 0.750 & 0.011 & 0.773 & 0.00 & - & \\
\hline \multirow[t]{2}{*}{ BETA } & -0.03 & -0.02 & -0.01 & 0.03 & -0.01 & -0.02 & -0.03 & 0.02 & 0.02 & 0.01 & -0.05 & 0.08 & -0.01 & 1 \\
\hline & 0.459 & 0.594 & 0.681 & 0.480 & 0.738 & 0.633 & 0.487 & 0.631 & 0.561 & 0.693 & 0.283 & 0.087 & 0.800 & - \\
\hline
\end{tabular}


Afterwards for each of hypotheses, the F-Chaw test and Hasman test is done separately and the regression results are analyzed by $\mathrm{t}$ statistic, the probability of $\mathrm{t}$, the $\mathrm{F}$ statistic and its probability and the determining coefficient.

Table 3: The information related to determining the method used for the first hypothesis

\begin{tabular}{cccc}
\hline $\begin{array}{c}\text { The indexes and } \\
\text { Result of test }\end{array}$ & The statistic & The meaningfulness level & result \\
\hline F & 8.36 & 0.000 & Panel data \\
Husman & 132.52 & 0.000 & Efficiency of consistent effect \\
\hline
\end{tabular}

Regarding the results of table (3). the regression test must be done via the panel data method of consistent effects.

Table 4: The model of consistent effects for the first hypothesis

\begin{tabular}{|c|c|c|c|c|}
\hline \multicolumn{5}{|c|}{$\mathrm{INC}_{\mathrm{jt}+1}=\beta_{0}+\beta_{1} \mathrm{CFO}_{\mathrm{jt}}+\beta_{2} \mathrm{OAC}_{\mathrm{jt}}+\beta_{3} \mathrm{CONSQ}_{\mathrm{jt}}+\beta_{4} \mathrm{CONSQ}_{\mathrm{jt}} * 0 A \mathrm{C}_{\mathrm{jt}}+\mathrm{s}_{\mathrm{jt}}$} \\
\hline variables & coefficients & Standard error & T Statictic & The meaningfulness effect \\
\hline $\mathrm{CFO}$ & -0.046 & 0.050 & -0.92 & 0.355 \\
\hline $\mathrm{OAC}$ & 0.048 & 0.015 & 3.07 & 0.002 \\
\hline CONSQ & -0.000 & 0.000 & -0.937 & 0.348 \\
\hline $\mathrm{CONSQ}^{*} \mathrm{OAC}$ & -0.000 & 0.000 & -0.409 & 0.682 \\
\hline Constant & 0.199 & 0.009 & 21.47 & 0.000 \\
\hline \multicolumn{5}{|c|}{ F Statistic:11.06 } \\
\hline \multicolumn{5}{|c|}{ The meaningful of F statistic: 0.0000} \\
\hline \multicolumn{5}{|c|}{ The foefficient of determination:0.66 } \\
\hline \multicolumn{5}{|c|}{ The adjusted foefficient of determination:0.60 } \\
\hline \multicolumn{5}{|c|}{ The Durbin-Watson test:1.67 } \\
\hline
\end{tabular}

Regarding the analysis of coefficients of the model whose results are shown in table (4), observing the meaningfulness level, the $t$ of each variables shows that only the variable of operative commitment items has positive and meaningful relationship with the future benefit of the company and there is no meaningful relationship between other variables. The variable CONSQ*OAC has no meaningful relationship with the future benefit of the company either. F shows the overall credit of the company. Based on the results in table (4), the calculated $F$ is larger than the $\mathrm{F}$ in the table $(\mathrm{p}<\% 5)$. So we can state that this model is meaningful with the probability of 95 percent. In other words, it could be said that this model has high credits. Also, regarding the meaningfulness level of $t$ about the constant and the independent variable coefficient, which is fewer than $5 \%$, the meaningfulness level of coefficient can be proved, and 
also the determination level of this model is 6 percent. This number shows that 6 percent of the dependent variable is expressed by the independent one. Also, the Durbin-Watson statistic shows that the problem of autocorrelation does not exist among the variables of the model. For testing the second hypothesis, firstly we observe the data types regarding the results of table (5):

Table 5: The information related to the determination of the usable method for the second hypothesis

\begin{tabular}{c|ccc}
\hline $\begin{array}{c}\text { The indexes and } \\
\text { Result of test }\end{array}$ & The statistic & The meaningfulness level & result \\
\hline F & 1.019 & 0.163 & Mixed method research \\
\hline
\end{tabular}

The results show that for testing the second hypothesis, the mixed data method should be used.

Table 6: The POOL model for the second hypothesis

\begin{tabular}{|c|c|c|c|c|}
\hline \multicolumn{5}{|c|}{ 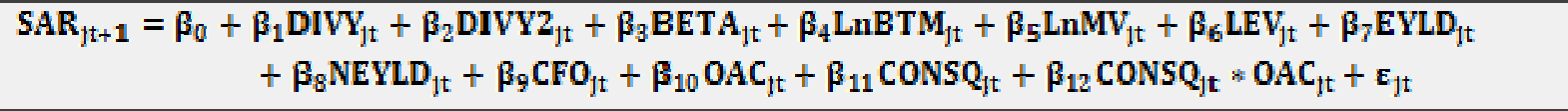 } \\
\hline variables & coefficients & $\begin{array}{c}\text { Standard } \\
\text { error }\end{array}$ & T Statictic & $\begin{array}{l}\text { The meaningfulness } \\
\text { effect }\end{array}$ \\
\hline DIVY & 0.021 & 0.084 & 0.259 & 0.795 \\
\hline DIVY^2 & -0.002 & 0.001 & -1.35 & 0.175 \\
\hline BETA & 0.011 & 0.058 & 0.191 & 0.848 \\
\hline LnBTM & -1.27 & 0.292 & -4.35 & 0.000 \\
\hline LnMV & 0.042 & 0.113 & 0.370 & 0.711 \\
\hline LEV & 0.015 & 0.032 & 0.466 & 0.640 \\
\hline EYLD & -2.005 & 1.85 & -1.08 & 0.279 \\
\hline NEYLD & 4.096 & 1.203 & 3.40 & 0.000 \\
\hline $\mathrm{CFO}$ & -0.392 & 1.18 & -0.331 & 0.740 \\
\hline $\mathrm{OAC}$ & 0.326 & 0.510 & 0.639 & 0.523 \\
\hline CONSQ & -0.001 & 0.001 & -1.13 & 0.258 \\
\hline CONSQ*OAC & -0.003 & 0.002 & -1.60 & 0.110 \\
\hline constant & -4.19 & 3.10 & -1.34 & 0.177 \\
\hline \multicolumn{5}{|c|}{ F Statistic:5.88 } \\
\hline \multicolumn{5}{|c|}{ The meaningful of F statistic: 0.0000} \\
\hline \multicolumn{5}{|c|}{ The foefficient of determination:0.137 } \\
\hline \multicolumn{5}{|c|}{ The adjusted foefficient of determination:0.114 } \\
\hline \multicolumn{5}{|c|}{ The Durbin-Watson test:2.14 } \\
\hline
\end{tabular}


fewer than $5 \%$, the meaningfulness level of coefficient can be proved. Also the determination level of this model is 11 percent. This number shows that 11 percent of the dependent variable is expressed by the independent one. Also, the Durbin-Watson statistic shows that the problem of autocorrelation does not exist among the variables of the model.

\section{Conclusions and Recommendations}

In this research, the relationship between conservatism and accrual persistence and stock returns was studied. The previous studies regarding conservatism and its effect on accrual and stock return stated that conservatism, increases the consistency of accruals and the return of stocks. ( Garcia et al 2012, Low and Nisism 2004, Basu 1997). Generally, the findings in this study do not agree with the expectations. Explaining this disagreement, the following issues can be addressed.

The results in this study indicate the use of bold accounting methods in companies. This can be the reason for the existence of the weak structure in rules and standards. So that it is possible to manipulate the accrual items and real activities and increase the operative risk. If the measured standards are not appositely compiled, we should not expect that the revelation standards could reflect the results of performance, like benefits and financial situation (balance sheet) well and present appropriate information to users for economical decisions. The tendencies of investors to achieve short-term interests and the main role of main investors in the market of stocks are of effective variables. For clear comments regarding how the existence of these variables affect the results of this study, needs other studies.

The period of the current study is since 2009 until 2015. During these years the stock market was mainly affected by political and economical news and factors like oil and dollar prices and political factors affected this economical index. Therefore prices and return of the capital was mainly influenced by information other than the numbers in financial statements. The fluctuations of index (highly increasing or decreasing) during this period expresses that the total capital of the company ( notwithstanding the specific features of the company) was affected. Therefore, these factors have thwarted the effects of the specific features of reporting of a company, like conservatism.

Therefore, regarding the results of this study, it is recommended that:

The producers of the theoretical basis of financial reports and financial accounting standards are advised to determine the position of the theoretical basis and the specific qualitative features of financial reporting's regarding the accounting processes and the existent situations in the stock market of the country.

The stock and securities organization of Tehran can consider supervisions resulting in increasing the control on market and the quality of information, regarding the incompetence of ratified standards in improving the conservatism, in order to decrease the risk of investors as a result of the high-quality information. 
Bulletin de la Société Royale des Sciences de Liège, Vol. 86, special edition, 2017, p. 587 - 601

\section{References}

[1] Karami. Q, Omrani. H,(2010), The impact of corporate life cycle and conservatism on the value of the company ", review of accounting and auditing, Issue 59, pp. 79-96.

[2] Vadie. M, Hoseini. M,(2012),Relationship between abnormal stock returns and performance evaluation. Quarterly accounting empirical research. Volume 1, Number 4, pp.73-84.

[3] Basu, S.( 1997). The conservatism principle and the asymmetric timeliness of earnings. Journal of Accounting and Economics 24:3-37.

[4] Dechow, P. \& Dichev, I. (2002). The quality of accruals and earnings: The role of accrual estimation errors". The Accounting Review. 77, 35-59.

[5] Financial Accounting Standards Board, (1978), Statement of Financial Accounting Concepts No. 1, Objectives of Financial Reporting by Business Enterprises, Stamford, Ct.

[6] García, J.M, and G. Beatriz and F. Penalva (2012).Accounting conservatism and the limits to earnings management.http://ssrn.com/abstract.

[7] LaFond, R., and R. Watts, 2008, "The Information Role of Conservatism", The Accounting Review (forthcoming). Availble at URL.

[8] Lev, B., T. Sougiannis. (1996). The Capitalization, Amortization and Value Relevance of R\&D. Journal of Accounting and Economics (21): 3-75.

[9] Watts, R. L, 2003. Conservatism in Accounting Part II: Evidence and Research Opportunities. Accounting Horizons, pp287-301. 